\title{
Kajian Aspek Ergonomi Face Shield untuk Covid-19
}

\author{
S. Slamet ${ }^{1, *}$, A. Sokhibi ${ }^{2}$, S. Harmoko ${ }^{3}$, Hariyanto $^{4}$, Suyitno $^{5}$ \\ 1,3,4Program studi Teknik Mesin, Fakultas Teknik, Universitas Muria Kudus \\ 2Program studi Teknik Industri, Fakultas Teknik, Universitas Muria Kudus \\ 5Program studi Teknik Mesin, Fakultas Teknik, Universitas Gadjah Mada \\ Kampus Gondang manis PO. Box 53, Bae-Kudus Telp/Fax: (0291) 438229 / 437198 \\ ${ }^{3}$ Centre for Innovation of Medical Equipments and Devices (CIMEDs), Fakultas Teknik, Universitas Gadjah Mada \\ `E-mail: sugeng.slamet@umk.ac.id
}

\begin{abstract}
Abstrak
Face shield sebagai alat pelindung diri harus mampu memberikan rasa aman dan nyaman bagi si pemakai. Face shield mampu memblokir partikel droplet yang mengandung kuman termasuk virus Covid-19. Di masa pandemi Covid-19 permintaan alat pelindung diri khususnya face shield mengalami peningkatan siginifikan. Produk face shield yang kurang memperhatikan aspek ergonomi dapat menyebabkan keluhan dari pemakai. Riset ini menguji aspek ergonomi pada face shield produksi Universitas Muria Kudus. Pengujian ergonomi dilakukan dengan metode evaluatif dengan memggunakan data variabel antropometri kepala orang Indonesia. Data antropometri tersebut digunakan sebagai bahan evaluasi terhadap kenyamanan produk face shield Universitas Muria Kudus. Sedangkan data keluhan pengguna face shield yang diproduksi Universitas Muria Kudus tersebut diperoleh dari responden berjumlah 41 orang, berumur antara 20-25 tahun, berjenis kelamin laki-lakidengan prosentase $85 \%$ dan perempuan dengan prosentase $15 \%$ serta dari suku jawa. Responden diberikan sejumlah pertanyaan terkait keluhan yang dirasakan saat menggunakan face shield Universitas Muria Kudus. Adapun variabel aspek perancangan produk yang diukur meliputi panjang face shield, lebar face shield, lingkar kepala face shield, tinggi kaca dan jarak mata ke kaca face shield. Variabel tersebut akan memberikan masukan ke produk akan kenyamaan dan keluhan yang dialami pengguna. Hasilnya menunjukkan bahwaface shield produksi Universitas Muria Kudus memenuhi aspek ergonomi, yaitu 4 (empat) ukuran bagian face shield tidak melebihi pada ukuran data antropometri kepala (persentile $95^{\text {th }}$ ) yaitu pada bagian panjang face shield, lebar face shield, lingkar kepala face shield dan jarak mata ke kaca. Dan terdapat 1 (satu) ukuran bagian face shield yang dapat dievaluasi aspek ergonominya, yaitu pada bagian lingkar kepala face shield dengan rentang (persentile $5^{\text {th }}$-persentile $95^{\text {th }}$ ). Dikarenakan pada bagian tersebut dipasang tali yang dapat diatur (adjustable).
\end{abstract}

Kata kunci : ergonomi, face shield, antropometri, responden.

\begin{abstract}
Face shields as a personal protective device must provide a sense of security and comfort for the wearer. In addition, face shields can block droplet particles that contain germs, including the Covid-19 virus. During the Covid-19 pandemic, the demand for personal protective equipment, especially face shields, has increased significantly. However, face shield products that do not pay attention to ergonomic aspects can cause complaints from users. Therefore, this research examines the ergonomic aspects of the face shield produced by the Universitas Muria
\end{abstract}


Kudus.Ergonomic testing is carried out using an evaluative method using anthropometric data on the heads of Indonesian people. Anthropometric data is used as material for evaluating the comfort of the Universitas Muria Kudus face shield product. Meanwhile, data on complaints from face shield users produced by Muria Kudus University were obtained from 41 respondents, aged between 20-25 years, males with a percentage of $85 \%$, women with a percentage of $15 \%$, and Javanese ethnicity. Respondents were given some questions about the complaints they felt when using the Universitas Muria Kudus face shield. The product design aspects measured include the face shield's length, the face shield's width, the circumference of the head of the face shield, the height of the glass, and the distance between the eyes and the face shield. These variables will provide input to the product about the comfort and complaints experienced by users. The results showed that the face shield produced by the Universitas Muria Kudus met the ergonomics aspect, namely four sizes of the face shield did not exceed the anthropometric data size of the head ( $95^{\text {th }}$ percentile), namely the length of the face shield, the width of the face shield, head circumference, and eye distance to the glass. There is one side of the face shield that can be evaluated for ergonomic aspects, namely the head circumference of the face shield with a range $\left(5^{\text {th }}\right.$ percentile $-95^{\text {th }}$ percentile) because the attached rope can be adjusted.

Keywords: ergonomic, face shield, anthropometry, respondents.

\section{PENDAHULUAN}

Pandemi Covid-19 merupakan suatu wabah penyakit baru yang ditemukan pertama kali di Wuhan (China) dan sudah menginfeksi 90.308 orang per tanggal 2 maret 2020. Gejala umum yang ditimbulkan berupa demam, batuk dan sulit bernapas. Penularan Covid-19 yang begitu cepat dan mematikan ini terjadi umumnya melalui droplet dan kontak dengan virus dan kemungkinan penularan di masa inkubasi menyebabkan masa kontak pasien ke orang sekitar lebih lama sehingga risiko jumlah kontak tertular dari 1 pasien mungkin dapat lebih besar (Zhu et al., 2020).

Salah satu cara melindungi diri dari penularan COVID-19 adalah dengan menggunakan Alat Pelindung Diri (APD). Pemakaian APD harus dianggap sebagai garis pertahanan terakhir dan hanya digunakan ketika pengendalian sebaran infeksi menjadi sulit dan tidak efektif. Namun APD dapat digunakan sesuai dengan potensi bahaya yang ada baik di tempat kerja ataupun ruang-ruang publik (B. Arifin dan A. Susanto, 2012). Beberapa jenis APD yang diwajibkan atau disarankan untuk mencegah penularan COVID-19 adalah masker (mask), pelindung wajah (face shield), dan sarung tangan. APD tersebut bertujuan untuk mencegah paparan virus ke dalam tubuh ataupun menularkan virus ke orang lain. Meskipun seluruh APD tersebut bermanfaat dalam mencegah penularan, APD dapat memiliki risiko yang mengancam keselamatan selama penggunaan (Y. Theopilus, 2020). Faktor kenyamanan dalam pemakaian APD merupakan faktor penting yang harus diperhatikan.

Face shield adalah tameng muka transparan yang dapat menutupi wajah untuk mencegah droplet mengandung virus memasuki mata, hidung, dan mulut (T. Ravenscroft, 2020). Face shield merupakan APD yang banyak digunakan oleh pekerja medis maupuan pekerja non medis. Namun dengan merebaknya wabah COVID-19, saat ini face shield banyak pula digunakan oleh masyarakat umum. Hal ini disebabkan fungsinya yang cukup efektif melindungi dari risiko terinfeksi COVID-19. APD ini juga banyak tersedia di pasaran dan harganya terjangkau, bahkan dapat dibuat sendiri dengan peralatan sederhana. Sebuah studi menggunakan simulator batuk 
yang menyemburkan aerosol yang mengandung virus influenza (W. G. Lindsleyv dkk, 2014) dengan jelas menunjukkan bahwa penggunaan face shield dapat menahan paparan virus sebesar 68\%-96\% pada jarak $46 \mathrm{~cm}$ dari sumber batuk dan sesaat setelah batuk, bergantung pada diameter droplet $(3,4-8,5 \mu \mathrm{m})$. Gambar 1 menunjukkan alat pelindung diri (APD) face shield.

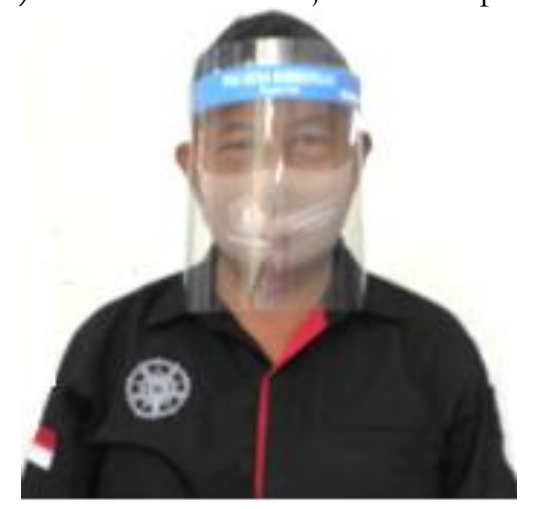

Gambar 1. Alat pelindung diri face shield

Penggunakan face shield sebelum era pandemi Covid-19 bukanlah produk yang umum untuk digunakan oleh pekerja maupun masyarakat umum. Sehingga produksi face shield skala besar maupun skala kecil sangat banyak di pasaran. Hal ini sangat bermanfaat bagi masyarakat, tetapi disisi lain ada faktor yang perlu diperhatikan dalam pembuatan atau perancangan face shield tersebut, yaitu faktor ergonomi. Ergonomi merupakan ilmu yang sistematis untuk memanfaatkan informasi mengenai kemampuan dan keterbatasan manusia dalam merancang suatu sistem kerja. Dengan demikian orang dapat hidup dan bekerja pada sistem dengan lebih baik untuk mencapai tujuan yang diinginkan melalui suatu pekerjaan yang efektif, efisien, aman dan nyaman (S. Wignjosoebroto, 2003).

Perancangan yang baik dapat dihasilkan dengan mengenal sifat-sifat keterbatasan, serta kemampuan yang dimiliki manusia. Manusia berperan sentral dalam aktifitasnya yaitu sebagai perencana, perancang, pelaksana dan pengevaluasi dalam setiap aktifitas kerja. Perancangan peralatan secara ergonomi perlu dilakukan dengan berpedoman pada prinsip-prinsip ergonomi (M. Andriani and Subhan, 2016). Setiap aktivitas atau pekerjaan yang dilakukan, apabila tidak dilakukan secara ergonomi akan mengakibatkan ketidaknyamanan, biaya tinggi, kecelakaan dan penyakit akibat beban kerja meningkat, performansi menurun yang berakibat kepada penurunan efisiensi dan produktifitas. Dengan demikian penerapan ergonomi pada suatu produk APD adalah suatu keharusan. Implementasi ergonomi di bidang manufaktur mampu meningkatkan produktifitas hingga 46\% dengan adanya pengurangan beban kerja yang tidak perlu. Penerapan ergonomi memberikan dampak positif pada keluhan muskuloskeletal, pengurangan kecelakaan kerja, klaim kompensasi terhadap kecelakaan kerja serta mengurangi ketidakhadiran pekerja karena sakit (D. Yunus, 2018).

Berdasarkan latar belakang tersebut, tujuan dari penelitian ini adalah untuk mengevaluasi face shield produksi Universitas Muria Kudus dari aspek ergonomi. Hal ini penting dilakukan, dikarenakan salah satu tahapan dalam merancang sebuah produk yang baik adalah memasukkan aspek ergonomi. Face shield yang dibuat tanpa memperhatikan aspek ergonomi berpotensi menimbulkan ketidaknyamanan dan keluhan bagi pemakai. 


\section{METODE PENELITIAN}

Metode yang digunakan dalam penelitian ini adalah metode evaluatif, dimana proses produksi yang akan dijalankan terlebih dahulu mempertimbangkan nilai-nilai positif dan keuntungan suatu program serta teknik yang akan digunakan (S. Arikunto, 2007). Pengumpulan data dalam penelitian ini dilakukan dengan pengambilan data sekunder antropometri kepala orang suku Jawa, berumur 20-25 tahun dan pengambilan data primer berupa data ukuran face shield yang diproduksi Universitas Muria Kudus. Objek penelitian ini adalah evaluasi ergonomi pada face shield produksi Universitas Muria Kudus. Oleh karena itu, kuesioner dibagikan kepada pengguna face shield yang diproduksi Universitas Muria Kudus untuk mengetahui kenyamanan dan evaluasi perbaikan dari face shield tersebut. Kuesioner dibagikan kepada responden berjenis kelamin laki-laki dan perempuan secara acak dengan jumlah responden diambil mengikuti persamaan Slovin:

$$
\begin{gathered}
n=\frac{N}{1+N e^{2}} \\
=500\left(1+500 \times 0,15^{2}\right) \\
=40,82 \approx 41 \text { orang }
\end{gathered}
$$

Dimana :

$\mathrm{n} \quad=$ jumlah sampel (orang)

$\mathrm{N} \quad=$ jumlah populasi pemakai face shield uji (orang)

e $\quad=$ Batas toleransi kesalahan (error tolerance)

Jawaban kuesioner dari responden selanjutnya dilakukan uji validasi dan uji reabilitas. Uji validasi digunakan untuk mengukur apakah kuesioner yang telah diberikan kepada responden itu stabil, akurat dan unsur-unsurnya homogen. Sedangkan uji reabilitas digunakan untuk mengetahui tingkat konsistensi dari responden tehadap variabel yang ada sehingga data yang diperolehakan cenderung memberikan hasil yang sama (konsisten).

Adapun data primer yang berupa data ukuran face shield yang diproduksi Universitas Muria Kudus digunakan untuk menentukan ukuran face shield terhadap kepala manusia sebagaimana ditunjukkan pada Gambar 2, meliputi bagi-bagian berikut:

a. Panjang face shield

Untuk panjang face shield, data antropometri yang digunakan adalah panjang kepala.

b. Lebar face shield

Untuk lebar face shield, data antropometri yang digunakan adalah lebar kepala.

c. Lingkar kepala face shield

Untuk lingkar face shield, data antropometri yang digunakan adalah lingkar kepala.

d. Tinggi kaca face shield

Untuk tinggi kaca face shield, data antropometri yang digunakan adalah tinggi kepala.

e. Jarak mata ke kaca face shield

Untuk jarak mata ke kaca face shield, data antropometri yang digunakan adalah tinggi mata ke kepala. 


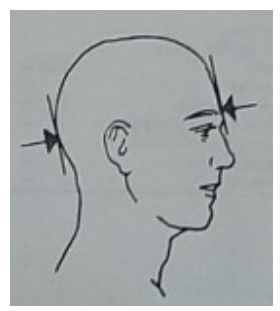

(a)

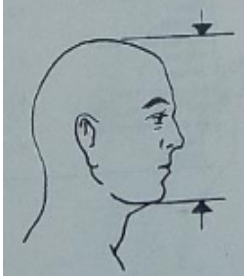

(d)

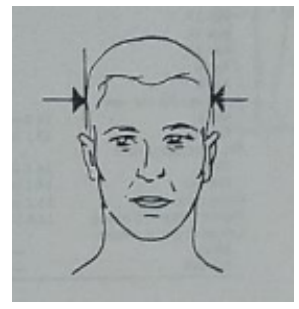

(b)

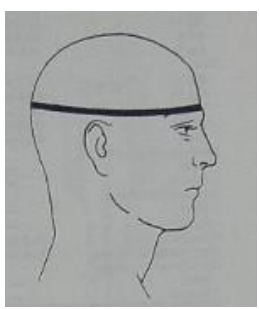

(c)

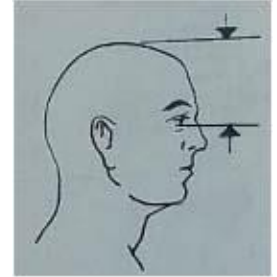

(e)

Gambar2. Antropometri kepala manusia (Sumber : Human Factors Design Handbook)(W. E.

Woodson, 1981)

\section{HASIL DAN PEMBAHASAN}

\subsection{Data hasil kuesioner pengguna face shield produksi Universitas Muria Kudus}

\section{a. Uji validitas}

Uji validitas dilakukan untuk mengukur apakah kuesioner yang telah diberikan kepada responden itu stabil, akurat dan unsur-unsurnya homogen. Pengujian validitasi ini dilakukan dengan internal validity. Kriteria yang dipakai berasal dari dalam alat tes itu sendiri dan masingmasing item pada setiap variable dikorelasikan dengan nilai total yang diperoleh dari koefisien korelasi rendah dan tingkat signifikan, maka item yang bersangkutan gugur, taraf signifikan yang digunakan adalah 5\%. Data responden dikatakan valid, apabilan nilai $\mathrm{r}$ hitung $>\mathrm{r}$ tabel. Hasil uji validitas dapat dilihat pada'Tabel 1 berikut:

Tabel 1. Hasil Uji Validitas

\begin{tabular}{|c|c|c|c|c|}
\hline No & Variabel & r hitung & r tabel & Ket \\
\hline 1 & Frekuwensi pemakaian face shield UMK & 0,801 & 0,308 & Valid \\
\hline 2 & $\begin{array}{l}\text { Keluhan yang dialami pada saat pemakaian face } \\
\text { shield UMK Sakit pada dahi }\end{array}$ & 0,885 & 0,308 & Valid \\
\hline 3 & $\begin{array}{l}\text { Keluhan yang dialami pada saat pemakaian face } \\
\text { shield UMK Sakit pada lingkar kepala }\end{array}$ & 0,917 & 0,308 & Valid \\
\hline 4 & $\begin{array}{l}\text { Keluhan yang dialami pada saat pemakaian face } \\
\text { shield UMK Sakit pada kepala bagian belakang }\end{array}$ & 0,584 & 0,308 & Valid \\
\hline 5 & $\begin{array}{l}\text { Keluhan yang dialami pada saat pemakaian face } \\
\text { shield UMK Sakit pada leher bagian belakang }\end{array}$ & 0,439 & 0,308 & Valid \\
\hline 6 & $\begin{array}{l}\text { Sakit Keluhan yang dialami pada saat pemakaian } \\
\text { face shield UMK Sakit pada mata }\end{array}$ & 0,925 & 0,308 & Valid \\
\hline 7 & Perlu nya perbaikan desain face shield UMK & 0,911 & 0,308 & Valid \\
\hline
\end{tabular}


S. Slamet et al. / Journal of Mechanical Design and Testing 3(2), (2021), 93-102

\begin{tabular}{llllll}
\hline 8 & Perlu nya perbaikan kenyamanan face shield & 0,875 & 0,308 & Valid \\
& UMK & & & & \\
9 & Perlu nya perbaikan keamanan face shield UMK & 0,718 & 0,308 & Valid \\
\hline
\end{tabular}

Karena nilai $\mathrm{r}$ hitung $>\mathrm{r}$ table, maka data responden dapat dikatakan valid atau akurat

\section{b. Uji reabilitas}

Uji reliabilitas digunakan untuk melihat tingkat konsistensi dari responden tehadap variabel yang ada sehingga data yang diperoleh akan cenderung memberikan hasil yang sama (konsisten). Data bisa dikatakan reliable jika nilai Alpha $>$ nilai standardized item alpha. Tabel uji reabilitas dapat ditunjukkan padaTabel 2 berikut:

Tabel 2. Hasil Uji Reabilitas

\begin{tabular}{lll}
\hline No & Alpha & Standardized Item Alpha \\
\hline 1 & 0,9285 & 0,9239 \\
\hline
\end{tabular}
konsisten

Karena nilai Alpha >nilai standardized item, maka data responden dapat dikatakan

\subsection{Data Hasil Kuesioner Pengguna Face shield Produksi Universitas Muria Kudus}

Hasil kuesioner yang dibagikan kepada 41 responden pemakai face shield produksi Universitas Muria Kudus dapat dilihat pada Tabel 3:

Tabel 3. Hasil kuiseoner

\begin{tabular}{lllc}
\hline No & Variabel & \multicolumn{2}{c}{ Hasil Kesioner (\%) } \\
\cline { 3 - 4 } & & Ya & Tidak \\
\hline 1 & $\begin{array}{l}\text { Frekuwensi pemakaian face shield umk dengan durasi kurang } \\
\text { dari 4 jam }\end{array}$ & $20 \%$ & $80 \%$ \\
\hline 2 & Keluhan sakit pada dahi pada saat pemakaian face shield umk & $30 \%$ & $70 \%$ \\
\hline 3 & $\begin{array}{l}\text { Keluhan sakit pada lingkar kepalapada saat pemakaian face } \\
\text { shield umk }\end{array}$ & $35 \%$ & $65 \%$ \\
\hline 4 & $\begin{array}{l}\text { Keluhan sakit pada bagian belakang kepala pada saat } \\
\text { pemakaian face shield umk }\end{array}$ & $10 \%$ & $90 \%$ \\
\hline 5 & $\begin{array}{l}\text { Keluhan sakit pada leher pada saat pemakaian face shield } \\
\text { umk }\end{array}$ & $1 \%$ & $99 \%$ \\
\hline 6 & Keluhan sakit pada matapada saat pemakaian face shield umk & $40 \%$ & $60 \%$ \\
\hline 7 & Perlu nya perbaikan desain face shield umk & $50 \%$ & $50 \%$ \\
\hline 8 & Perlu nya perbaikan kenyamanan face shield umk & $(5 \%$ & $45 \%$ \\
\hline 9 & Perlu nya perbaikan keamanan face shield umk & $40 \%$ & $60 \%$ \\
\hline & Tabel 3 diatas menunjukan bahwa pertanyan kuesioner nomor 1 & & \\
\hline
\end{tabular}

untuk Tabel 3 diatas menunjukkan bahwa pertanyaan kuesioner nomor 1 sampai 6 adalah Sedangkan pertanyaan nomor 7 sampai 9 adalah pertanyaan untuk mengavaluasi perancangan face shield produksi UniversitasMuria Kudus. Kuesioner yang dibagikan kepada responden tersebut merupakan sempalan beberapa pertanyaan mengenai keluahan yang dirasakan pengguan prosuk yang terdapat pada kuesiooner Nordic Body Map. 


\subsection{Data antropometri}

Data antropometri selalu berhubungan dengan pengukuran dimensi pada tubuh manusia (S. Wignjosoebroto, 2000). Tabel 4 menunjukkan data persentile antropometri kepala orang suku Jawa.

Tabel 4. Data persentile antropometri kepala orang suku Jawa (Sumber: Ismianti dkk, 2019)

\begin{tabular}{llccc}
\hline No & Dimensi & Persentile5 th & Persentile50 th & Persentile95 th \\
\hline 1 & Panjang kepala & 17 & 19,20 & 21,50 \\
2 & Lebar kepala & 14 & 16,50 & 19,84 \\
3 & Lingkar kepala & 34,37 & 41 & 47,56 \\
4 & Tinggi kepala & 20,45 & 23 & 25,53 \\
5 & Tinggi Mata ke kepala & 9,5 & 12 & 14,84 \\
\hline
\end{tabular}

Persentile95th digunakan untuk ukuran face shield ergonomi, kecuali pada ukuran lingkar kepala face shield. Persentile ${ }^{95 t h}$ digunakan karena dapat mewakili populasi orang suku Jawa dengan ukuran kepala yang besar. Sehingga populasi orang suku Jawa yang mempunyai ukuran kepala kecil pun dapat menggunakan face shield tersebut. Tabel 5 menunjukkan data ukuran face shiled ergonomi.

Tabel 5. Data ukuran face shiled ergonomi

\begin{tabular}{llll}
\hline No & Bagianface shield & Ukuran $\mathbf{( c m )}$ & Ket \\
\hline 1 & Panjang face shield & 21,50 & Persentile95th \\
2 & Lebar face shield & 19,84 & Persentile95th \\
3 & Lingkar kepala face shield & $34,37-47,56$ & Persentile5th - Persentile95th \\
4 & Tinggi kaca face shield & 25,53 & Persentile95th \\
5 & Jarak mata ke kaca face & 14,84 & Persentile5th \\
& shield & & \\
\hline
\end{tabular}

\subsection{Data face shield produksi Universitas Muria Kudus}

Adapun data ukuran face shield produksi Universitas Muria Kudus dapat dilihat pada Tabel 6, sedangkan Gambar 3 menunjukkan teknik pengukuran untuk mendapatkan data antropometri kepala dengan face shield produksi UniversitasMuria Kudus.

Tabel 6. Data ukuran face shield produksi Universitas Muria Kudus

\begin{tabular}{llll}
\hline No & Bagianface shield & Ukuran $\mathbf{( c m )}$ & Keterangan \\
\hline 1 & Panjang face shield & 16,50 & Permanen \\
2 & Lebar face shield & 12,00 & Permanen \\
3 & Lingkar kepala face shield & $43,10-65,10$ & Adjustable \\
4 & Tinggi kaca face shield & 24,50 & Permanen \\
5 & Jarak mata ke kaca face shield & 12,45 & Permanen \\
\hline
\end{tabular}




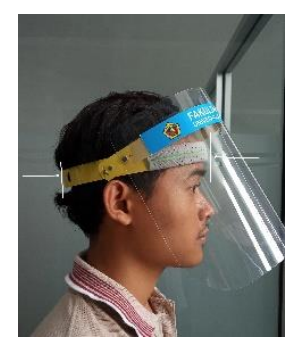

(1)

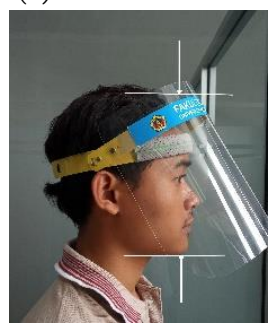

(4)

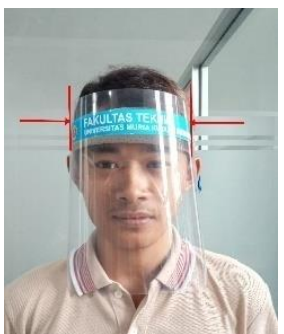

(2)

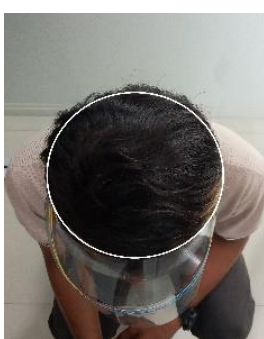

(3)

Gambar 3. Teknik pengukuran data antropometri

Bagian-bagian utama dari face shield produksi Universitas Muria Kudus sebagaimana ditunjukkan Gambar 4.

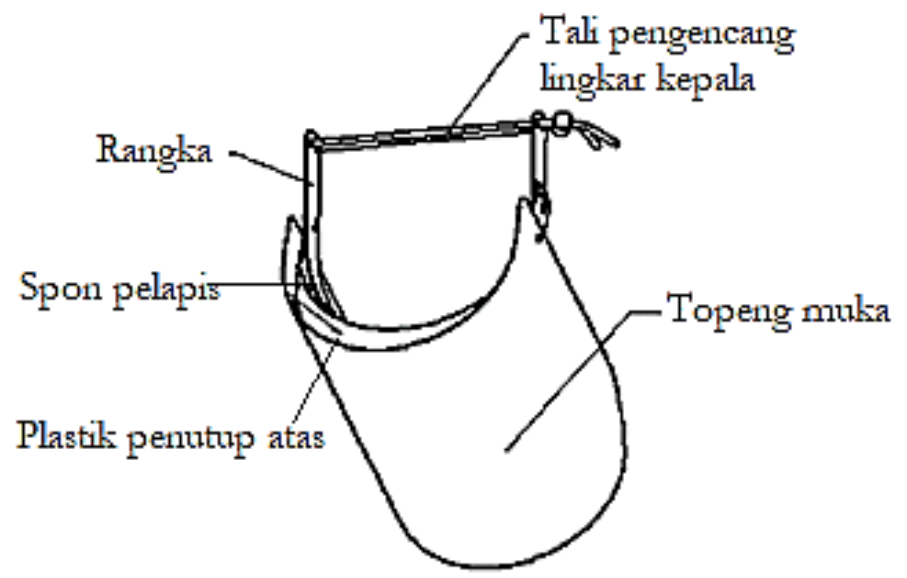

Gambar 4. Bagian-bagian utama face shield produksi Universitas Muria Kudus

\subsection{Pengujian aspek ergonomi face shield}

Pengujian dilakukan dengan mengevaluasi dan membandingkan data persentile ${ }^{95 t h}$ antropometri kepala orang suku Jawa dengan data dimensi face shield yang diproduksi oleh Universitas Muria Kudus (UMK). Tabel 7 menunjukkan perbandingan data persentile95th antropometri dimensi face shield produksi UMK. 
Tabel 7. Perbandingan data ukuran ukuran face shiled ergonomi suku Jawa dengan ukuran face shield produksi UMK

\begin{tabular}{llll}
\hline \multirow{2}{*}{ No } & Antropometri & $\begin{array}{l}\text { Data ukuran face shiled } \\
\text { ergonomi suku Jawa }\end{array}$ & $\begin{array}{l}\text { Data ukuran } \\
\text { face shield UMK } \\
\text { (cm) }\end{array}$ \\
\hline 1 & Panjang face shield & 21,510 & 16,50 \\
2 & Lebar face shield & 19,84 & 12,00 \\
3 & Lingkar kepala face shield & $34,37-47,56$ & $43,10-65,10$ \\
4 & Tinggi kaca face shield & 25,53 & 24,50 \\
5 & $\begin{array}{l}\text { Jarak mata ke kaca face } \\
\text { shield }\end{array}$ & 14,84 & 12,45 \\
\hline
\end{tabular}

Tabel 7 diatas menunjukkan terdapat 4 (empat) ukuran bagian face shield produksi Universitas Muria Kudus tidak melebihi pada ukuran data antropometri kepala orang suku Jawa (persentile 95th) yaitu pada bagian panjang face shield, lebar face shield, lingkar kepala face shield dan jarak mata ke kaca. Sehingga face shield produksi Universitas Muria Kudus dari aspek ukuran memenuhi aspek ergonomi. Terdapat 1 (satu) ukuran bagian face shield produksi Universitas Muria Kudus yang adjustable atau dapat diatur sesuai ukuran lingkar kepala pemakai yaitu pada bagian lingkar kepala face shield menggunakan tali pengencang. Sehingga menggunakan rentang persentilesth Sampai persentile ${ }^{95 t h}$. Untuk mengetahui adanya hubungan kesesuaian antara data ukuran face shield Universitas Muria Kudus dengan data ukuran face shiled ergonomi suku Jawa, maka dilakukan uji statistik dengan Uji Chi-Square dengan menggunakan tingkat kepercayaan 5\%. Adapun hasil Uji tersebut dapat dilihat pada Tabel 8.

Tabel 8. Hasil Uji kesesuaian

Chi-Square Tests

\begin{tabular}{ll|ll} 
& Value & df & $\begin{array}{l}\text { Asymptotic } \\
\text { Significance } \\
\text { sided) }\end{array}$ \\
\hline Pearson Chi-Square & $32.000^{a}$ & 16 & .010 \\
\hline Likelihood Ratio & 23.907 & 16 & .092 \\
\hline Linear-by-Linear Association 6.889 & 1 & .009 \\
\hline N of Valid Cases & 8 & & \\
\hline
\end{tabular}

Berdasarkan Hasil uji chie-square diatas, diketahuia nilai Asymp.sig sebesar 0,010. Karena nilai Asymp.sig 0,010 < 0,05, maka dapat disimpulkan bahwa HO ditolak dan $\mathrm{Ha}$ diterima. Dengan demikian dapat diartikan bahwa terdapat hubungan yang signifikansi atau sesuai antara data ukuran face shield Universitas Muria Kudus dengan data ukuran face shiled ergonomi suku Jawa. 


\section{KESIMPULAN}

Kesimpulan yang dapat diambil dari penelitian ini sebagai berikut:

1) Dimensi atau ukuran face shield produksi Universitas Muria Kudus memenuhi aspek ergonomi. Dikarenakan ukuran pada bagian-bagian face shield produksi Universitas Muria Kudus tidak melebihi ukuran persentile ${ }^{95 t h}$ dari data antropometri kepala orang suku Jawa.

2) Pengembangan produk face shield produksi Universitas Muria Kudus ini perlu ditingkatkan dari aspek kenyamanan. Hasil kuesioner kepada responden menunjukkan tingkat kenyamanan pada face shield UniversitasMuria Kudus sebesar 45\%.

\section{DAFTAR PUSTAKA}

Bustanul Arifin dan A. Susanto, 2012, "Faktor-Faktor Yang Berhubungan Dengan Kepatuhan Pekerja Dalam Pemakaian Alat Pelindung Diri (Apd) Di Bagian Coal Yard Pt X Unit 3 \& 4 Kabupaten Jepara Tahun 2012," J. Kesehat. Masy. Univ. Diponegoro, vol. 2, no. 1, p. 1 6, http:/ /ejournals1.undip.ac.id/index.php/jkm.

D. Yunus, 2018, "Peran Ergonomi Partisipatif dalam Mencegah Keluhan Muskuloskeletal," Ber. Kedokt. Masy., vol. 34, no. 5, pp. 3-6, https://jurnal.ugm.ac.id/bkm/article/view/37692.

Ismianti, Herianto, Ardiyanto, 2019, "Studi Antropometri Mahasiswa Indonesia Bersuku Batak Dan Jawa", Jurnal Ergonomi Indoneisia, vol. 05, no. 02, pp. 47-56, https://ojs.unud.ac.id/index.php/jei/article/view/55062.

M. Andriani and Subhan, 2016, "Perancangan peralatan secara ergonomi untuk meminimalkan kelelahan di pabrik kerupuk," Semin. Nas. sains dan Teknol. Fak. Tek. UMJ, Jakarta, 8 November, pp. 1-10, jurnal.umj.ac.id/index.php/semnastek\%0Ap-ISSN.

N. Zhu et al., 2020, "A Novel Coronavirus from Patients with Pneumonia in China " N. Engl. J. Med., vol. 382, no. 8, pp. 727-733, doi: 10.1056/nejmoa2001017.

S. Arikunto, 2007, Prosedur Penelitian Suatu Pendekatan Praktek, Rineka Cipta, Jakarta.

S. Wignjosoebroto, 2000, Evaluasi Ergonomi dalam Perancangan Produk. ITS, Surabaya.

S. Wignjosoebroto, 2003, Ergonomi, studi gerak dan waktu, Guna Widya, jakarta.

T. Ravenscroft, 2020, "Eight Face Shields Designed to Protect Corona Virus Healthcare Workers", bttps:// www.dezeen.com/2020/04/13/face-shields-coronavirus-apple-foster/ (accessed Jun. 09, 2020).

W. E. Woodson, 1981, Human Factors Design Handbook, Information \& Guidelines for the Design of Systems, Facilities, Equipment, and Products for Human Use, Mc. Graw-Hill Book Co, New York.

W. G. Lindsley, J. D. Noti, F. M. Blachere, J. V. Szalajda, and D. H. Beezhold, 2014, "Efficacy of face shields against cough aerosol droplets from a cough simulator," J. Occup. Environ. Hyg., vol. 11, no. 8, pp. 509-518, doi: 10.1080/15459624.2013.877591.

Y. Theopilus, T. Yogasara, C. Theresia, and J. R. Octavia, 2020, "Analisis Risiko Produk Alat Pelindung Diri (APD) Pencegah Penularan COVID-19 untuk Pekerja Informal di Indonesia," J. Rekayasa Sist. Ind., vol. 9, no. 2, pp. 115-134, doi: 10.26593/jrsi.v9i2.4002.115-134. 